\title{
Развитие архитектуры Казахстана на рубеже тысячелетий
}

\author{
Б.У.Куспангалиев, Институт архитектуры и строительства им. Т. Басенова КазНИТУ имени \\ К.И. Сатпаева, Алматы, Казахстан \\ К.И. Самойлов, Институт архитектуры и строительства им. Т. Басенова КазНИтУ имени \\ К.И. Сатпаева, Алматы, Казахстан
}

Своеобразная политико-экономическая ситуация начала 1990-х годов в Казахстане вызвала некоторое замедление ранее достаточно высоких темпов массового строительства жилья и общественных зданий.

Номенклатура субъектов проектной деятельности, ранее состоявшая преимущественно только из крупных проектных институтов различной степени специализации, пополнилась существенно потеснившими их и занявшими значительный сектор рынка многочисленными проектными и проектно-строительными фирмами, а также персональными творческими мастерскими и индивидуальными проектировщиками, берущимися практически за типологически любой объект.

Практически исчезло массовое типовое проектирование и строительство.

Важнейшей образной характеристикой архитектуры Казахстанана рубеже веков стала своего рода полистиличность.

В одну из характерных черт городской среды превратилась активная трансформация первых этажей.

Существенно обновилась типология городской застройки.

Резко расширилась, а в большинстве мест стала новым массовым явлением практика мемориального и особенно разноконфессионального культового строительства.

Важным аспектом стало освоение значительно расширившегося ассортимента конструкционных и особенно отделочных материалов и изделий, а также решение проблемы их совместимости с широко распространёнными. Значимой чертой архитектуры этапа стало, определённое этим массовое использование многоцветных сочетаний, включающих и очень насыщенные тона.

Отражая эти процессы, казахстанская архитектура современного периода демонстрирует широкие возможности как единовременного комплексного формирования отдельных участков среды жизнедеятельности «под ключ», так и последовательного «вживления» отдельных элементов в складывающийся средовой контекст.

Обретение государственной независимости Казахстаном активизировало и процессы архитектурной самоидентификации, имевшие многовекторную направленность.

Ключевые слова: Казахстан, архитектура, строительство, полистилизм, реконструкция, заказчик

\section{Development of Architecture in Kazakhstan at the Turn of the Millennium}

B.U.Kuspangaliev, T. Basenov Institute of Architecture and Construction, Satbayev University, Almaty, Kazakhstan

K.I.Samoilov, T. Basenov Institute of Architecture and Construction, Satbayev University, Almaty, Kazakhstan

The peculiar political and economic situation in the early 1990s in Kazakhstan caused a slight slowdown in the previously rather high rates of mass construction of housing and public buildings. The nomenclature of subjects of design activity, which previously consisted mainly only of large design institutes of various degrees of specialization, was replenished by numerous design and construction firms that have significantly squeezed them out and occupied an impactful market sector, as well as personal creative workshops and individual designers who took on almost any type of object. Mass-scale standard design and construction have practically disappeared.

The most important figurative characteristic of the architecture of Kazakhstan at the turn of the century was a kind of polystyle. The active transformation of the first floors has become one of the characteristic features of the urban environment.

The typology of urban development has been significantly updated.

The practice of memorial and especially multi-denominational religious construction has expanded dramatically, and in most places has become a new mass phenomenon.

The development of a significantly expanded assortment of construction and especially finishing materials and products, as well as solving the problem of their compatibility with widespread ones, has become an important aspect. The resulting massive use of multi-color combinations, including very rich tones, has become a significant feature of the architecture of that time. Reflecting these processes, the Kazakh architecture of the modern period demonstrates broad possibilities of both a one-time complex formation of separate sections of the environment of vital activity "on a turnkey basis", and sequential "implantation" of individual elements into the emerging environmental context.

The acquisition of state independence by Kazakhstan also intensified the processes of architectural self-identification, which had a multi-vector orientation.

Keywords: Kazakhstan, architecture, construction, polystylism, reconstruction, customer. 
Своеобразная политико-экономическая ситуация начала 1990-х годов в Казахстане вызвала некоторое замедление ранее достаточно высоких темпов массового строительства жилья и общественных зданий. Начавшийся процесс перераспределения собственности (особенно в сфере недвижимости) привёл к появлению многочисленных частных и корпоративных заказчиков, имеющих не только различные финансовые возможности, но и разнящиеся взгляды на решение объёмнопланировочных, материало-конструкционных и композиционно-пластических задач. Зачастую этот заказчик хорошо знаком с отечественной и мировой практикой строительства интересующего его типа зданий, имеет личные впечатления и сформировавшиеся на их основе идеи интерперетации, а в основном - комбинирования элементов для получения искомого результата. И главное - заказчик стал иметь экономическую возможность «продиктовать» специалистам своё видение практически во всех разделах и на всех стадиях проектирования, а также и по ходу строительства. «0правданием» этого является несение заказчиком практически всего бремени финансовых рисков и естественного в таких

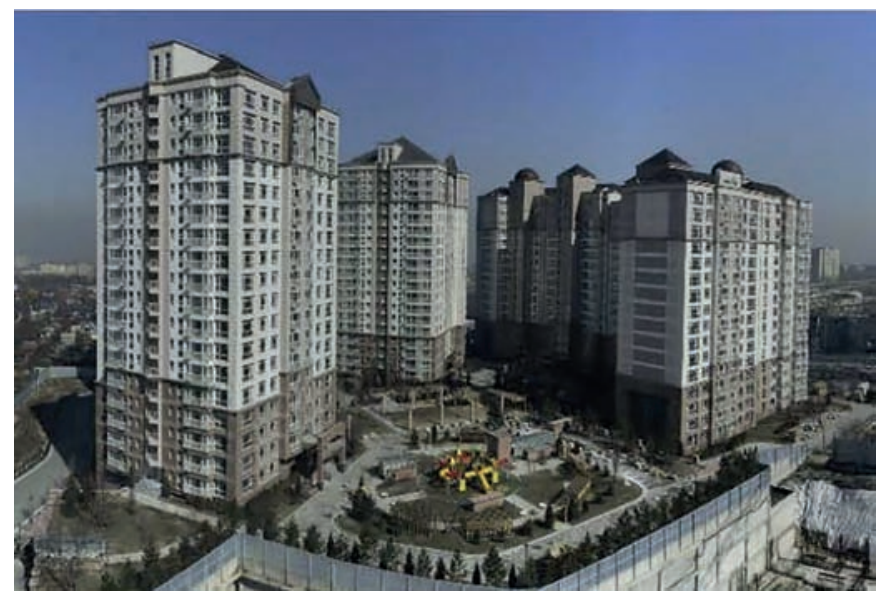

a)

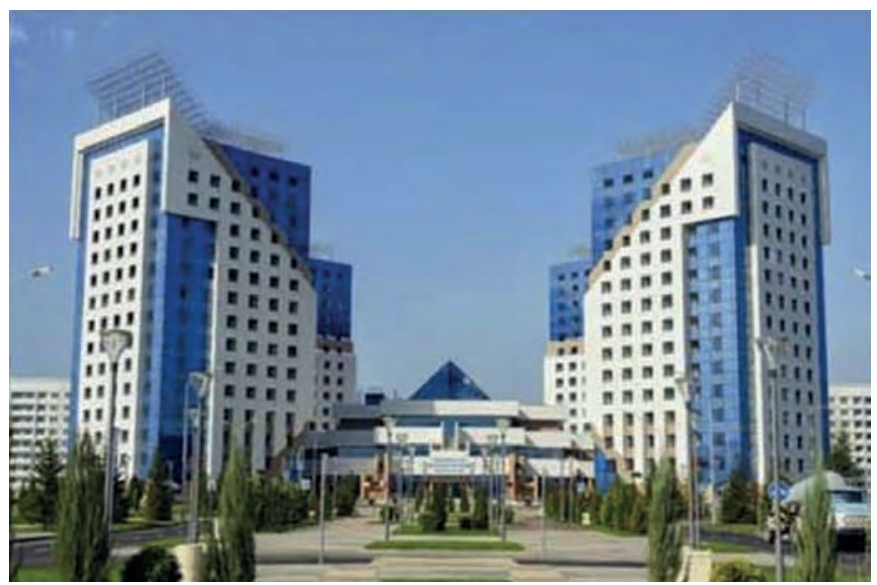

B) условиях желания проконтролировать точность реализации своих замыслов или, в исключительных случаях, принять к сведению часто - технические, иногда - юридические, редко - экономические и никогда - творческие обоснования их корректировки.

0собенность заключается в том, что такому заказчику, имеющему преимущественно универсальное мышление и весьма далёкому от когда-то доминировавшего в мировоззрении пиетета перед мифологизированным творчеством, по сути, безразличны средства реализации замысла и личностно-профессиональные проблемы специалистов. Критерием тендерного выбора исполнителей является прогнозируемое с определённой степенью точности гармоничное сочетание затрат и получаемого качества продукта, который должен обладать и достаточной вероятностью ликвидности, базирующейся на возможности частичной или полной переинтерпретации в зависимости от изменившейся потребности. Появляются соответствующие, хотя и несколько парадоксальные, модели новых подходов к проектированию, предполагающие изначальный учёт возможных реконструкций [4]. С другой

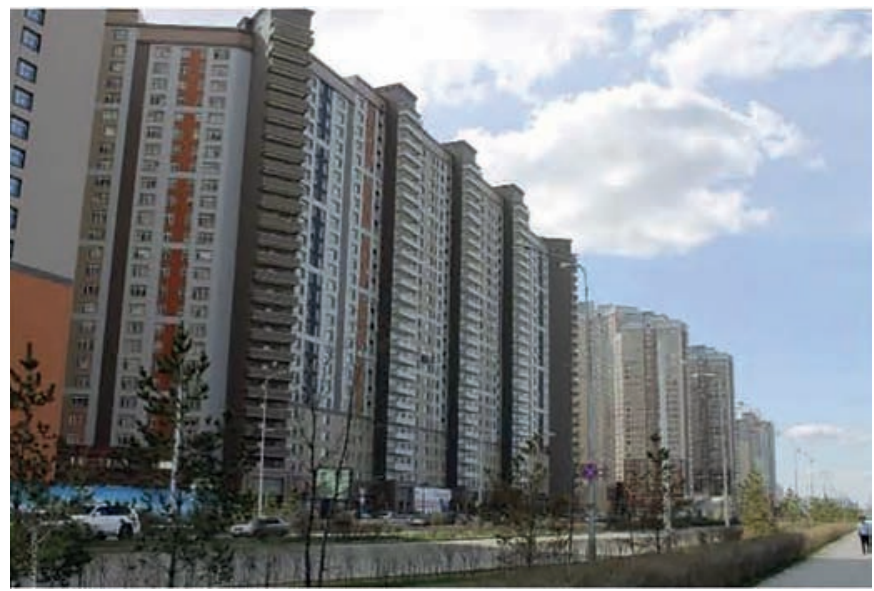

б)

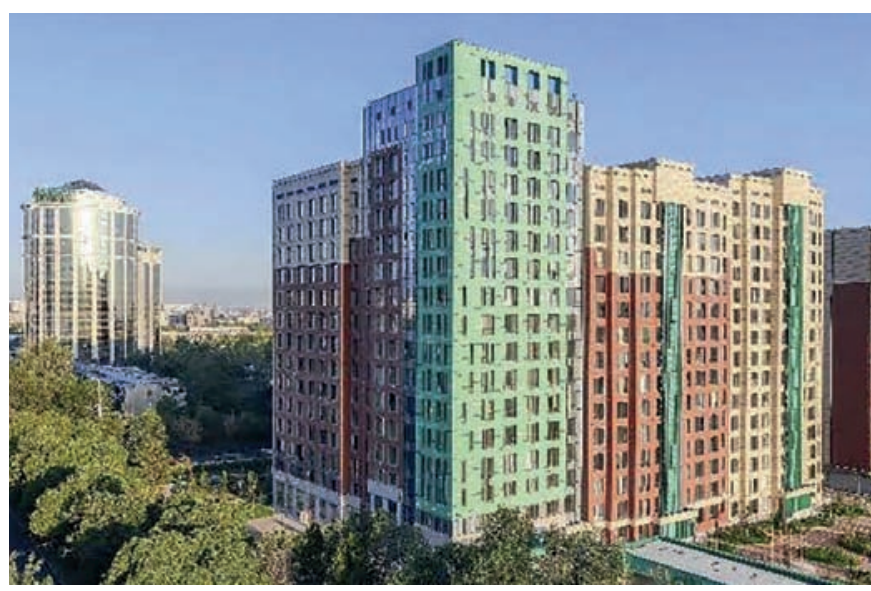

2)

Рис. 1. Примеры архитектуры Казахстана рубежа веков: а) комплекс «Эппл-Таун». Алматы. Архитектор Б. Куспангалиев; б) комплекс «Хай-Вилл». Нур-Султан. Архитектор Б. Куспангалиев; в) Олимпийская деревня. Алматы. Архитектор Ш. Юсупов; г) комплекс «Легенда». Алматы. Архитектор бюро «Базис-А» ${ }^{*}$

*) Все иллюстрации, использованные в статье, кроме особо оговоренных, взяты из открытых источников сети Интернет. 
стороны, этот «новый» (в том смысле, что его не было больше трёх четвертей века) заказчик достаточно податлив на проведение различных материало-конструкционных и особенно архитектурно-художественных экспериментов, что открывает дорогу очень интересным произведениям. Правда, часть из них в профессиональных кругах порицается за творческую вседозволенность и излишества.

Это послужило основой формирования особого типа универсально-синтетического специалиста, имеющего своеобразное базовое или перепрофилированное образование. Характерной его чертой становится и соответствующее ситуации мировоззрение: «Выступая в роли субъекта рынка, архитектор в значительной мере расстаётся с амбициями творца, даже если следует не чужой или внеперсональной, но своей собственной версии мира. <...> Уступчивость интересам рынка тем более характерна для стандартной фигуры практикующего архитектора, достаточно свободно меняющего языки, стили, переходящего от неоклассики к модерну,

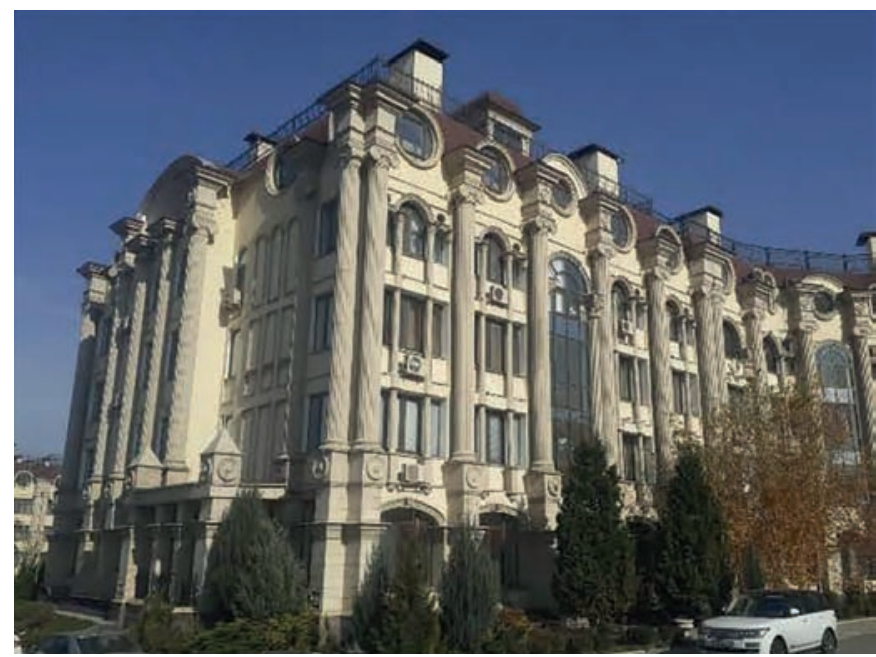

a)

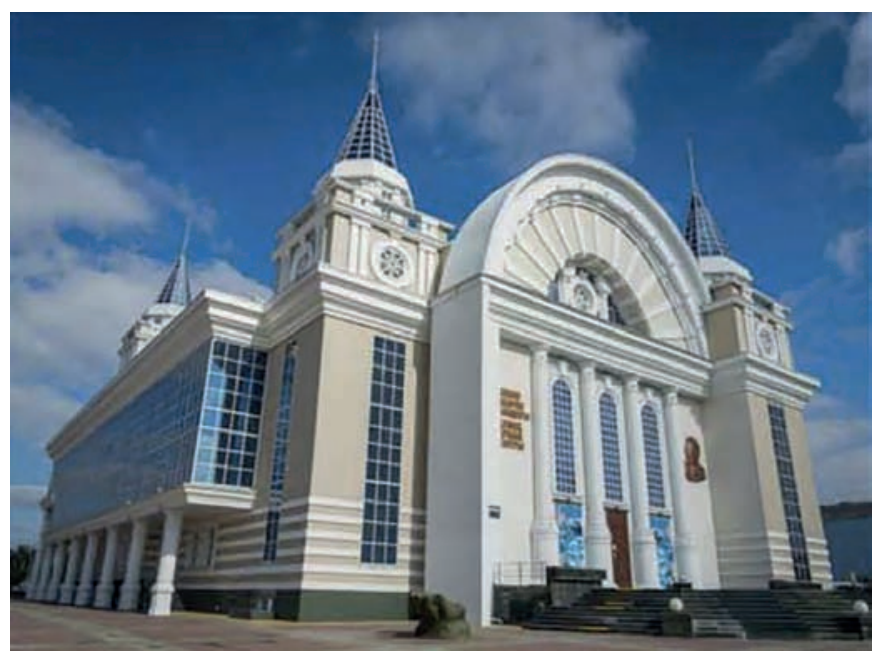

B) от модерна к фольклору и т.д., как правило, вне ощущения изменения собственно картины мира» [2, с. 169]. Причём номенклатура субъектов проектной деятельности, ранее состоявшая преимущественно только из крупных проектных институтов различной степени специализации, пополнилась существенно потеснившими их и занявшими значительный сектор рынка многочисленными проектными и проектностроительными фирмами, а также персональными творческими мастерскими и индивидуальными проектировщиками, берущимися практически за типологически любой объект, имея в виду возможность свободного кооперирования специалистов соответствующего профиля и изменения численности персонала в достаточно широких пределах. Резко возросла внутрипрофессиональная конкуренция. Большое значение для повышения квалификации имело сотрудничество отечественных зодчих с крупными иностранными фирмами, активно работавшими на казахстанском архитектурно-строительном рынке в последнем десятилетии XX века.

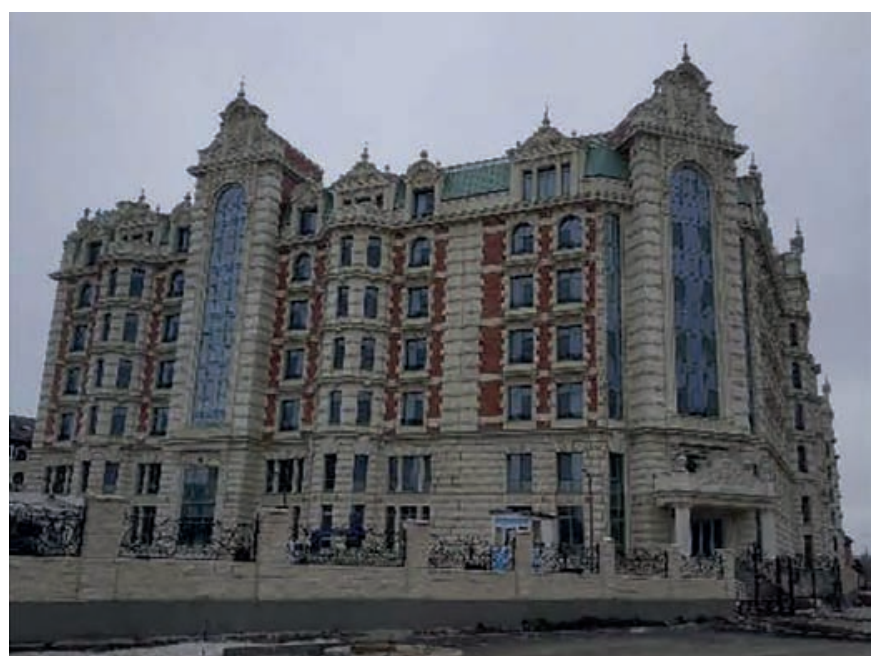

б)

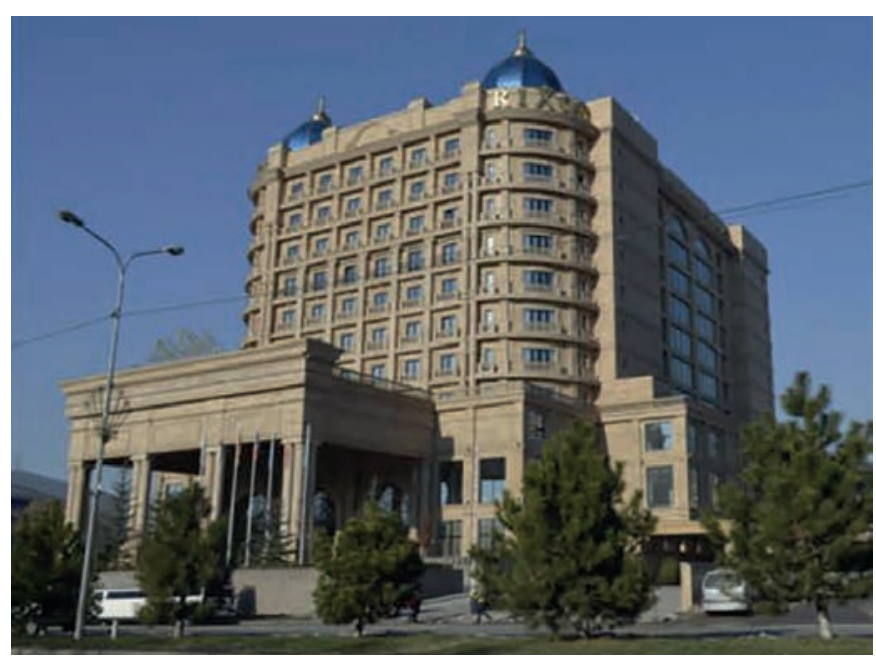

г)

Рис. 2. Примеры архитектуры Казахстана рубежа веков: а) комплекс «Европолис». Алматы. Архитектор К. (амойлов; б) комплекс «Байсанат». Нур-Султан; в) Областной казахский драматический театр им. И. Омарова. Костанай. Архитекторы В. Тоскин, В. Тоскина, В. Яроцкий; г) гостиница «Риксос Хадиша Шымкент». Шымкент. Архитектор А. Гулеткин 
Практически исчезло массовое типовое проектирование и строительство, так как каждое проектное решение рассматривается в качестве ноу-хау, распространение документации которого существенно снижает конкурентоспособность производителя, а юридическая фиксация авторских прав бесперспективна из-за сложности доказательств идентичности и невозможности эффективного отслеживания практики применения. С другой стороны, экономически обосновываемая заказчиком востребованность индивидуального облика часто встречающихся объектов расширила внутри проектных фирм практику повторного применения проектов с переработанными в той или иной степени фасадами при прямой или зеркальной привязке планировки, конструктивных и инженерно-технических решений. Показательно, что в определённой степени и для Казахстана возможно констатировать, отмечаемую, например, в российской архитектуре [9, с. 412] похожесть ряда организационно-деятельностных и стилевых аспектов рубежей XIX-XX и XX-XXI веков.

Взаимообусловленным стало и появление произведений, в которых априори наличествует сложность атрибутирования по видам с пространственно-параметрических и эксплуатационно-смысловых позиций. Ещё более проблематичным в

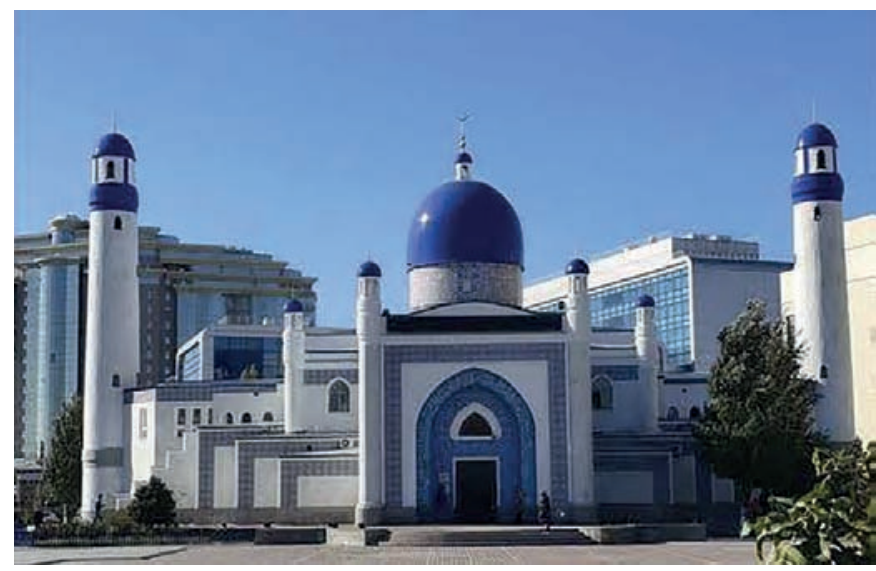

a)

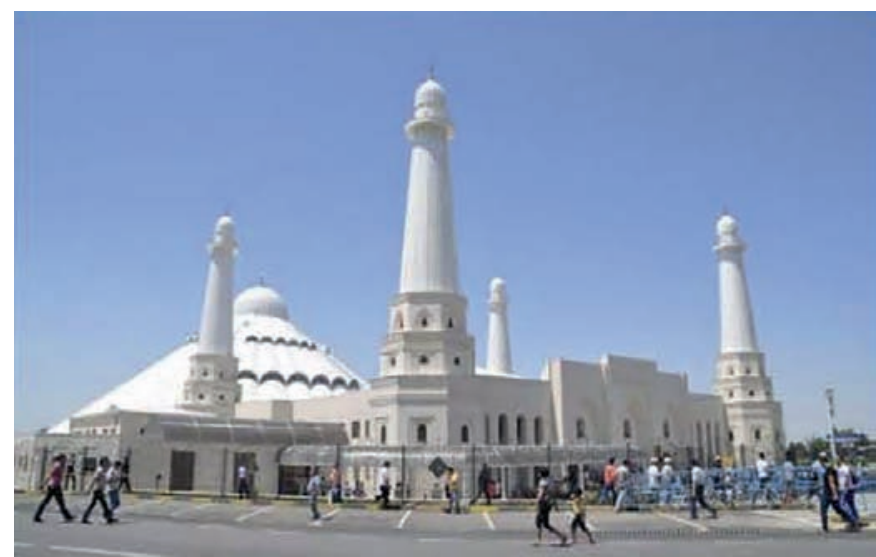

B) условиях зачастую вынужденной буквальной реализации персональных вкусовых предпочтений становится определение стилистической направленности как отдельных объектов, так и архитектуры в целом. Важнейшей образной характеристикой архитектуры Казахстана, как и ряда других стран, на рубеже веков стала своего рода полистилизм.

Массовая приватизация обусловила то, что в большинстве случаев собственниками жилого фонда, как отдельных частей, так и целых общественных и ряда промышленных зданий, стали независимые друг от друга юридические и физические лица. Соответственно, в одну из характерных черт городской среды превратилась активная трансформация первых этажей. Здесь, на месте квартир, крупных магазинов, столовых, помещений проектных и научно-исследовательских институтов появились небольшие магазины, кафе, парикмахерские, стоматологические кабинеты, модельные и игровые салоны, клубы, офисы и т.п. Такие предприятия, занимая часть здания, имеют самостоятельные входы с соответствующим козырьком или целым тамбуром и лестницей, выходящей на тротуар. Архитектурно-художественное решение каждого из них в большинстве случаев является подчёркнуто индивидуальным, контрастирующим с обликом остальной части здания. Кроме

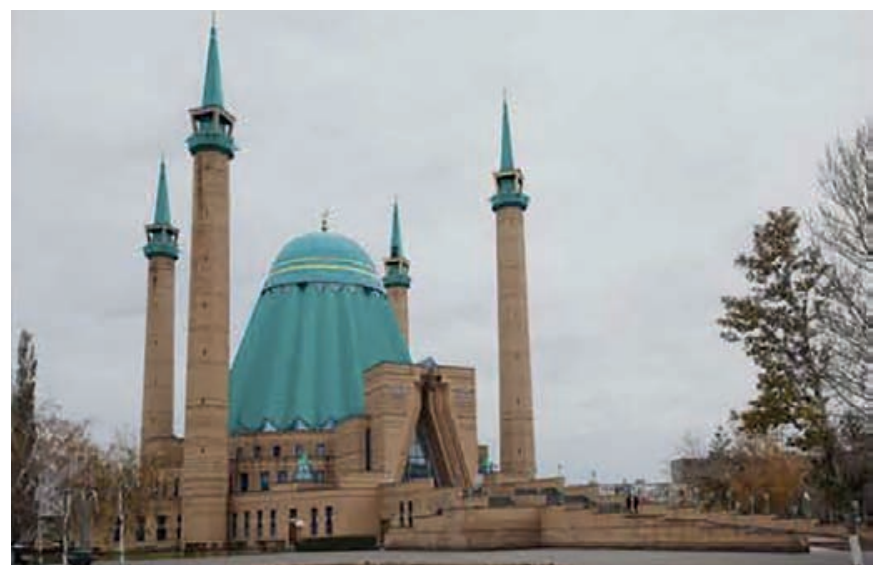

б)

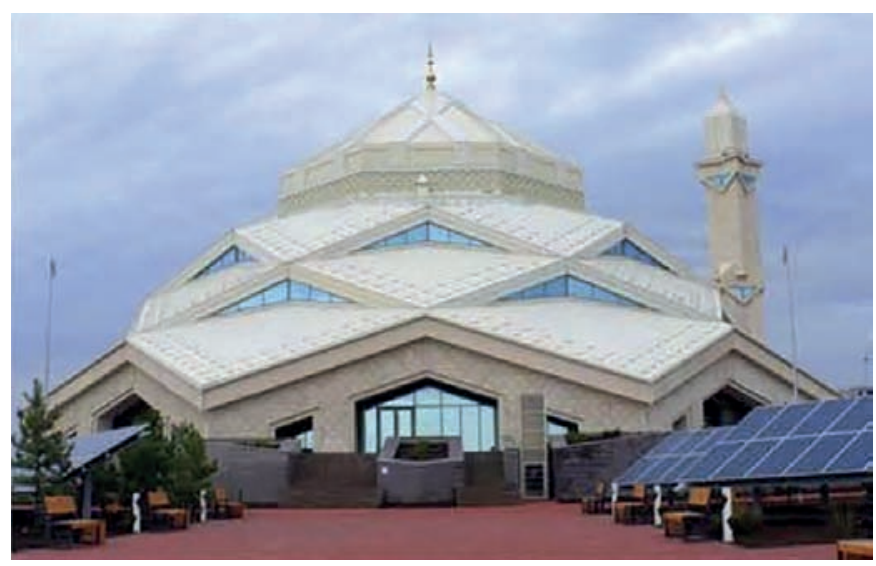

2)

Рис. 3. Примеры архитектуры Казахстана рубежа веков: а) мечеть. Атырау. Архитектор Ш. Юсупов; б) мечеть им. Машхура Жусупа. Павлодар. Архитекторы Т. Абильда, М. Кабдуалиев, Ш. Юсупов, С. Даутов, С. Нуррбай; в) мечеть. Шымкент; г) мечеть им. Рыскельды-кажи. Нур-Султан. Архитектор С. Жамбулатов 
того, в крупных городах эти предприятия меняют владельца, а то и профиль работы через два-три года. Это влечёт за собой расширение или уменьшение занимаемой ими площади, перепланировку помещений, реконструкцию фасада и прилегающей территории в соответствии со спецификой работы, вкусами и возможностями заказчика, а также интерпретацией этих составляющих авторами проекта.

Существенно обновилась типология городской застройки. Здания банков и бизнес-центров, офисы крупных компаний и здания со сдаваемыми в аренду помещениями, мини- и супермаркеты, закусочные и рестораны, раз-

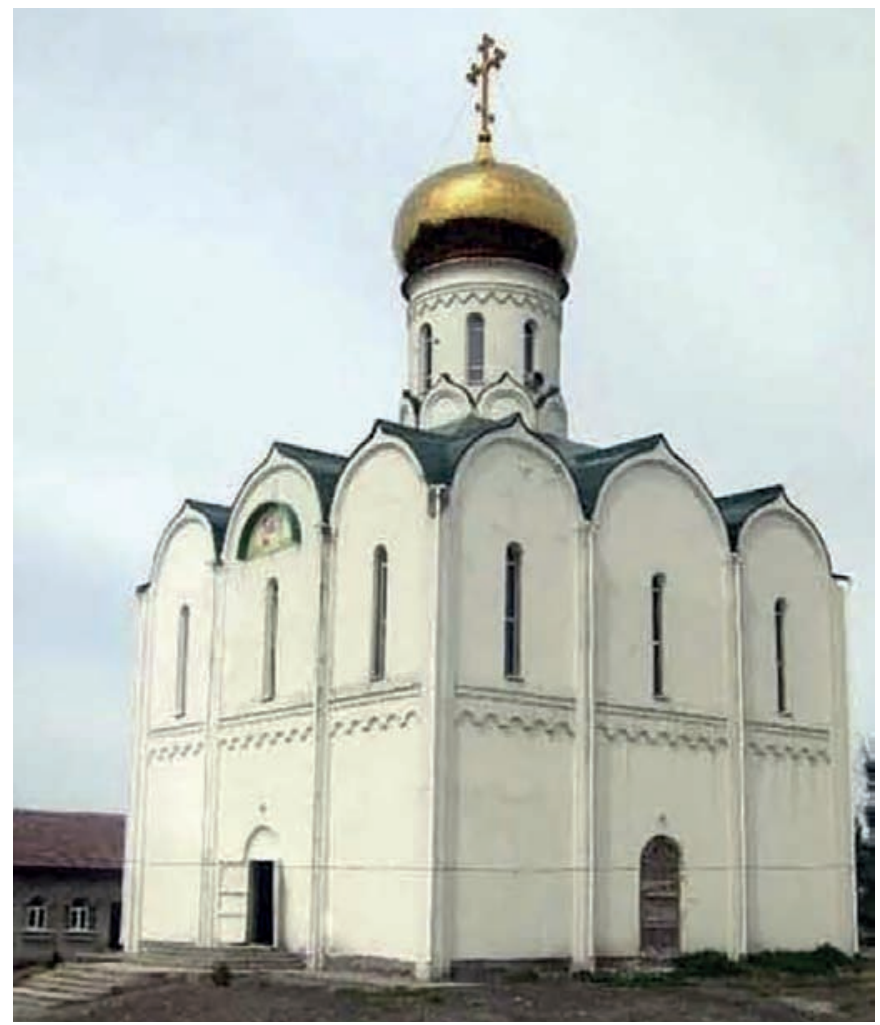

a)

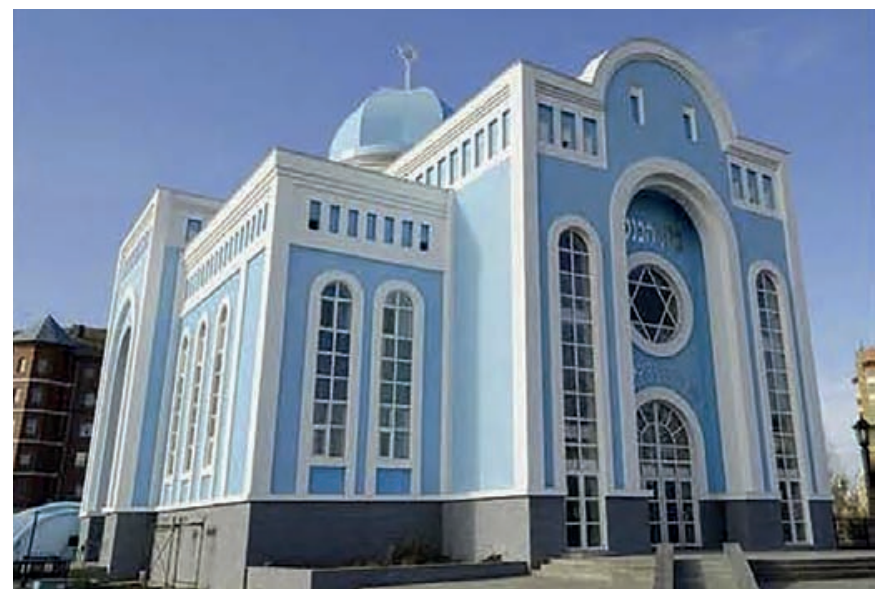

B) нообразные клубы и салоны, торгово-развлекательные и спортивные центры, казино и различной вместимости гостиницы стали существенной частью урбанистического пейзажа. Резко расширилась, а в большинстве мест стала новым массовым явлением практика мемориального и особенно разноконфессионального культового строительства. Констатируемый в развитии зодчества ряда соседних стран Содружества тот факт, что «в оживившемся культовом строительстве применение почти исключительно традиционных объёмно-пространственных структур, форм и деталей непосредственно предустанавливается заказчиком»

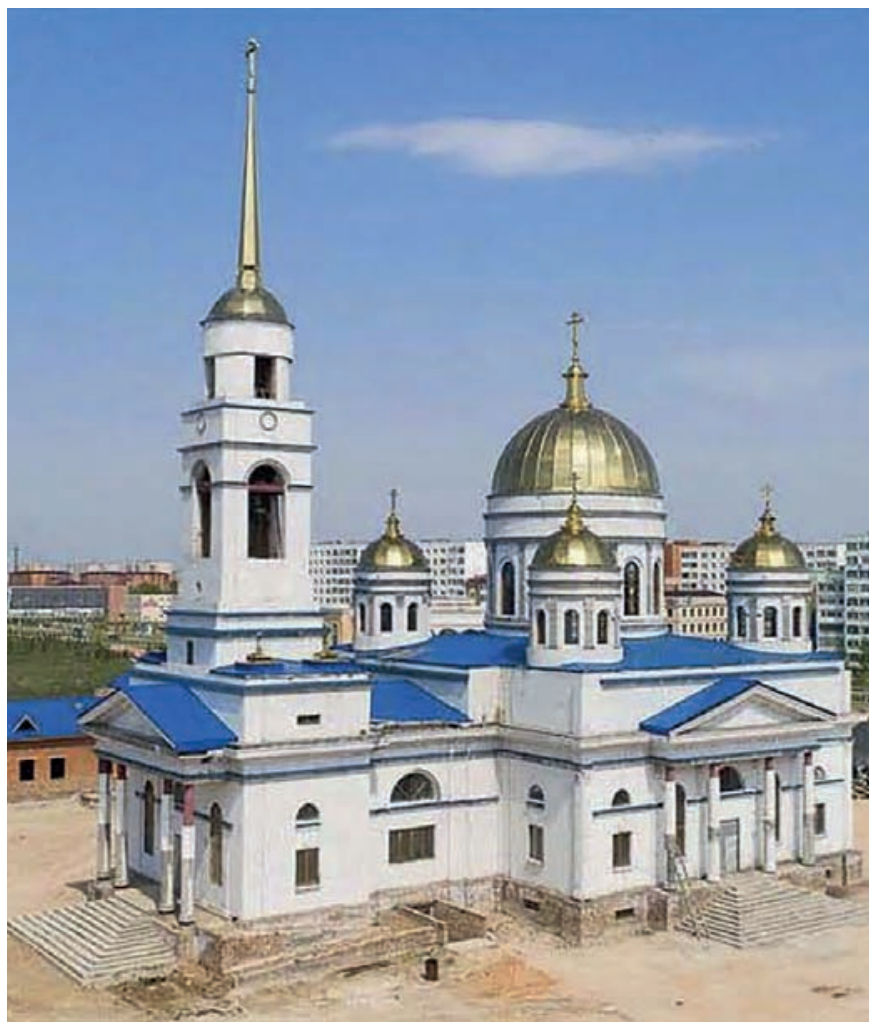

б)

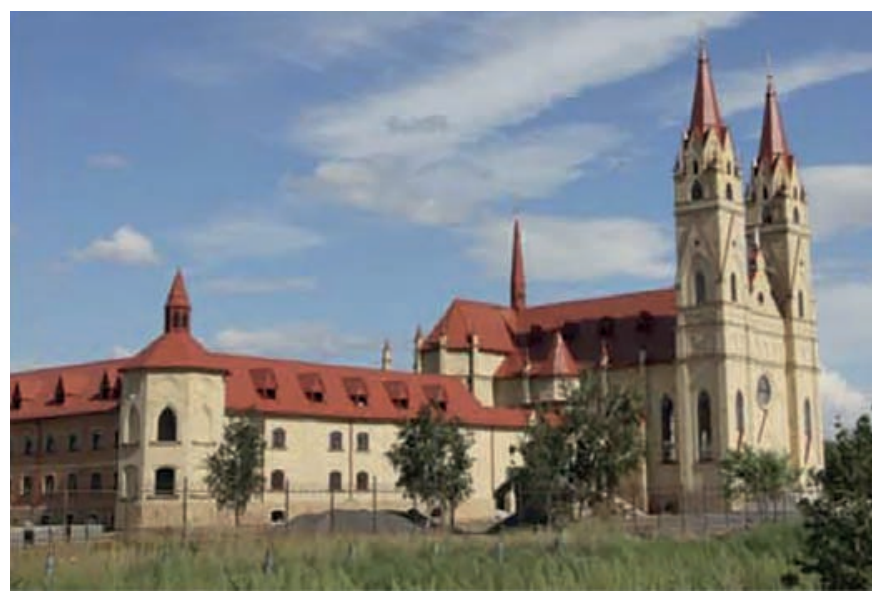

2)

Рис. 4. Примеры архитектуры Казахстана рубежа веков: а) храм святого архангела Гавриила. Талдыкорган. Архитектор Е. Подольская; б) храм Вознесения Христова. Кокшетау. Архитекторы Д. Белик, В. Маковяк; в) синагога Бейт Рахель Шабат Любавич. Нур-Султан; г) храм пресвятой Богородицы Фатимской. Караганда. Архитекторы К.-М. Руф, В. Сергеев 
[9, с. 419] характерен и для Казахстана. Вместе с тем ряд конфессий поддерживает и новационные архитектурнохудожественные решения.

Особый феномен - так называемое «элитное жильё» различной этажности и степени изоляции от массовой застройки. Под это, ставшее расхожим определение, обычно попадает вся застройка, несмотря на достаточно чёткие рыночные критерии степени комфортабельности: собственно «элитное», «клубное» и жильё «эконом-класса». Проектирование этих объектов стало серьёзнейшим профессиональным экзаменом, ибо, по сути, для заказчика критерием мастерства зодчего, а, соответственно, и возможностью его «выживания» на рынке является быстрая реализация квартир или особняков. Это касается как новостроек, так и реконструкций. Из прошедших «отбор» сформировался своего рода класс «модных» архитекторов, состав которого эпизодически обновляется.

Важным аспектом стало освоение значительно расширившегося ассортимента конструкционных и особенно отделочных материалов и изделий, а также решение проблемы их совместимости с широко распространёнными. Значимой чертой архитектуры этапа стало определённое этим массовое использование многоцветных сочетаний, включающих и очень насыщенные тона. Постоянно изменяющаяся палитра

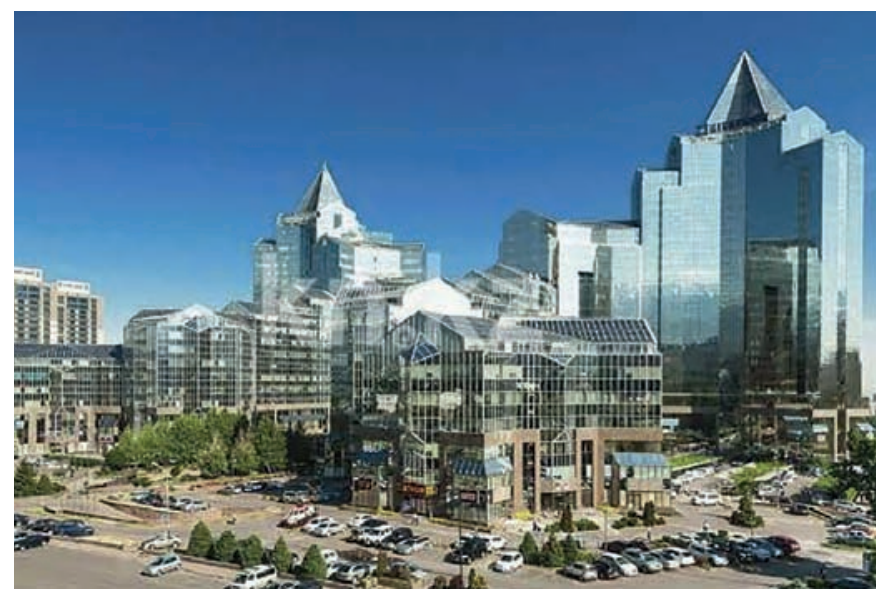

a)

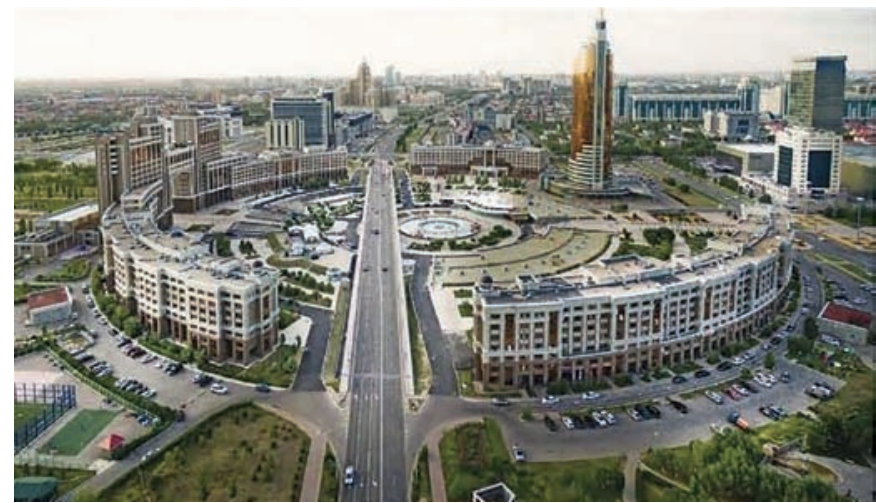

B) отделочных материалов даже при сохранении профиля предприятия и занимаемого им объёма стимулирует владельцев на переделки фасадов для сохранения экономически привлекательного имиджа фирмы. Постепенно это во всё большей степени стало касаться и организаций, занимающих те или иные здания полностью. Широкое применение получили разноразмерные и разношрифтовые надписи, зачастую активно включённые в образное решение построек.

Отражая эти процессы, казахстанская архитектура современного периода демонстрирует широкие возможности как единовременного комплексного формирования отдельных участков среды жизнедеятельности «под ключ», так и последовательного «вживления» отдельных элементов в складывающийся средовой контекст. Причём на всех этапах: от формирования замысла на базе многоаспектного консалтинга, его проектной интерпретации, до реализации - законами рынка гарантировано чёткое следование критерию соответствия персональному видению заказчика, и, конечно же, учёт его динамики.

Широко распространяющаяся с 1990-х годов концепция «устойчивого развития» к рубежу веков из узкого природоохранного сектора переросла в глобальную стратегию сохранения культуры. Важная роль архитектуры в этом процессе всё более активно осмысляется и в адаптации к региональным

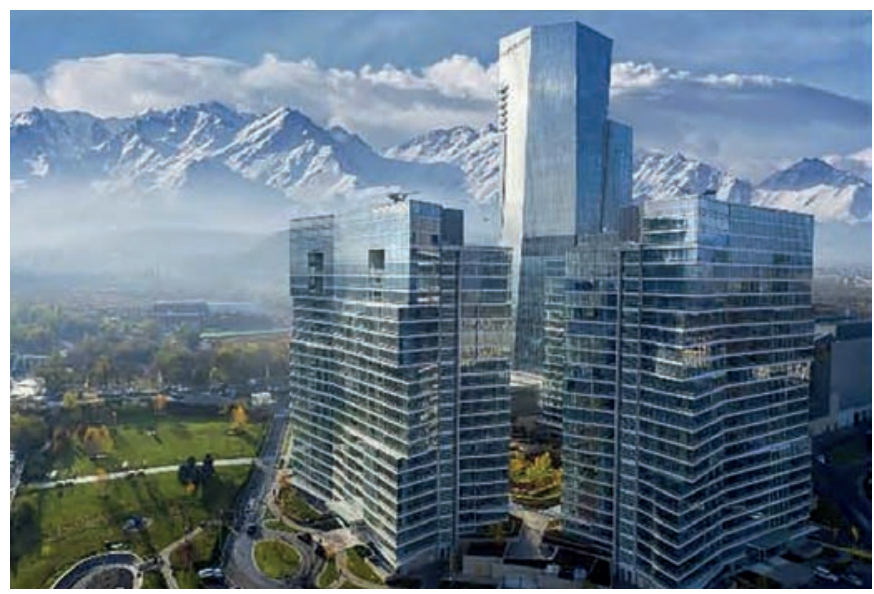

б)

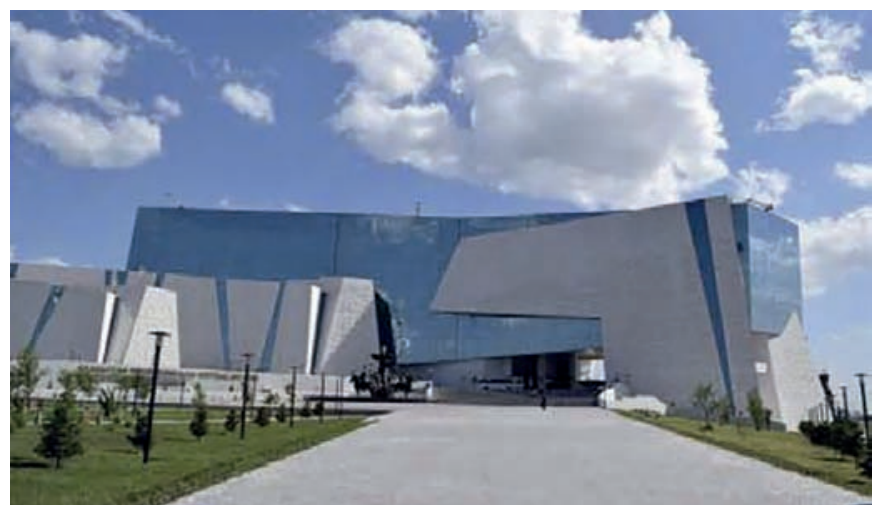

2)

Рис. 5. Примеры архитектуры Казахстана рубежа веков: а) комплекс «Нурлы-Тау». Алматы. Архитекторы Т. Ералиев, С. Баймагамбетов; б) комплекс «Есентай-Парк». Алматы. Архитектурное бюро «Скидмор, Оуингс, Меррил»; в) Нур-Султан. Овальная площадь. Архитектор Н. Борискин; г) Исторический музей. Нур-Султан. Архитектор В. Лаптев 


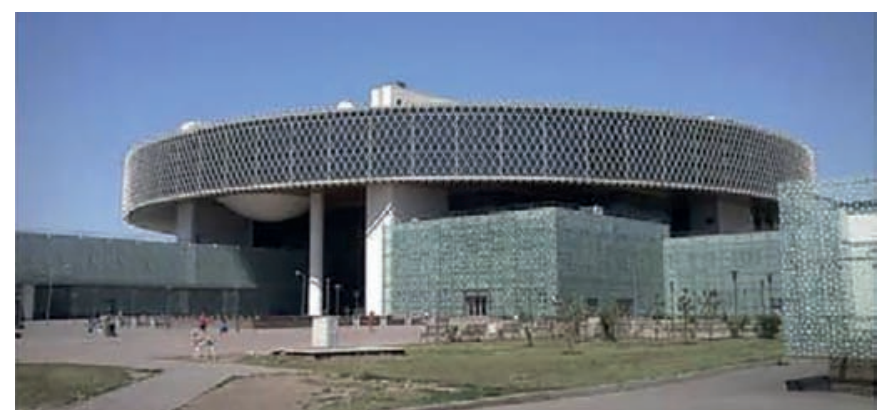

a)

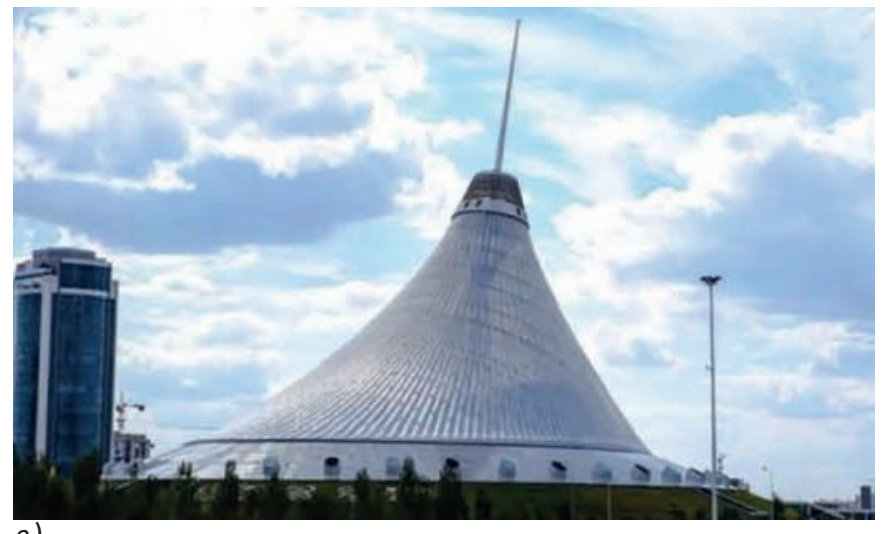

B)

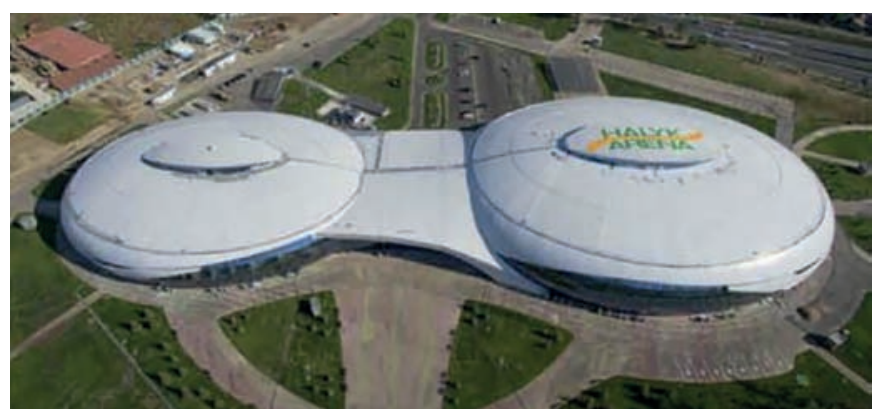

б)

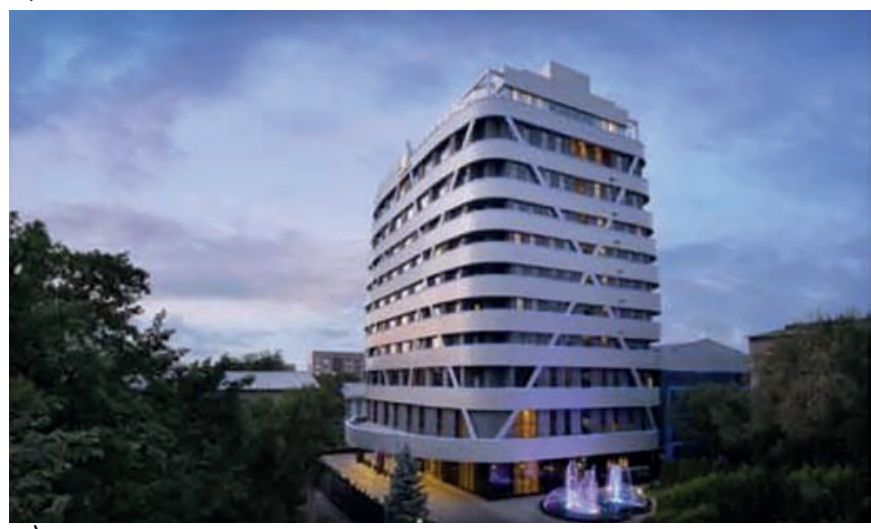

2)

Рис. б. Примеры архитектуры Казахстана рубежа веков: а) Дворец школьников. Нур-Султан. Архитектор Н. Явейн; б) спорткомплекс «Халык-Арена». Алматы; в) комплекс «Хан-Шатыр». Нур-Султан. Архитектор Н. Фостер; г) гостиница «Дабл-Трии». Алматы

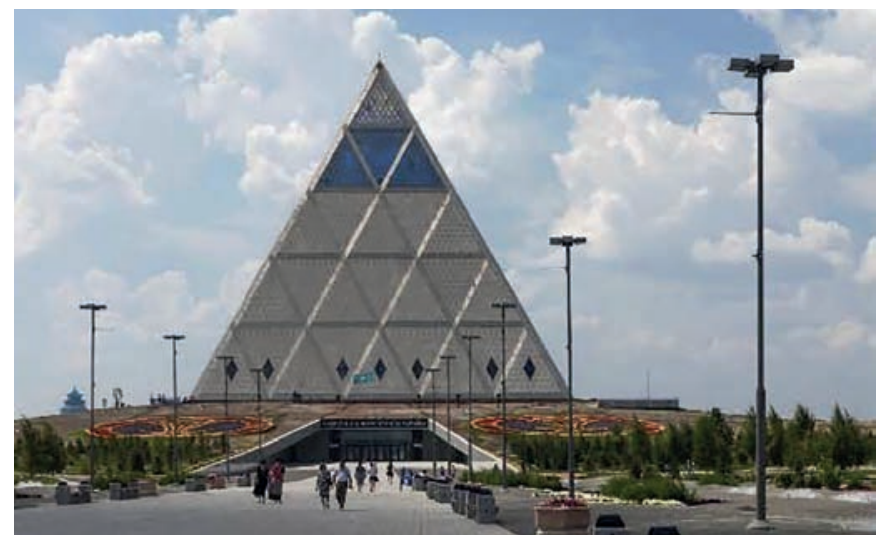

a)

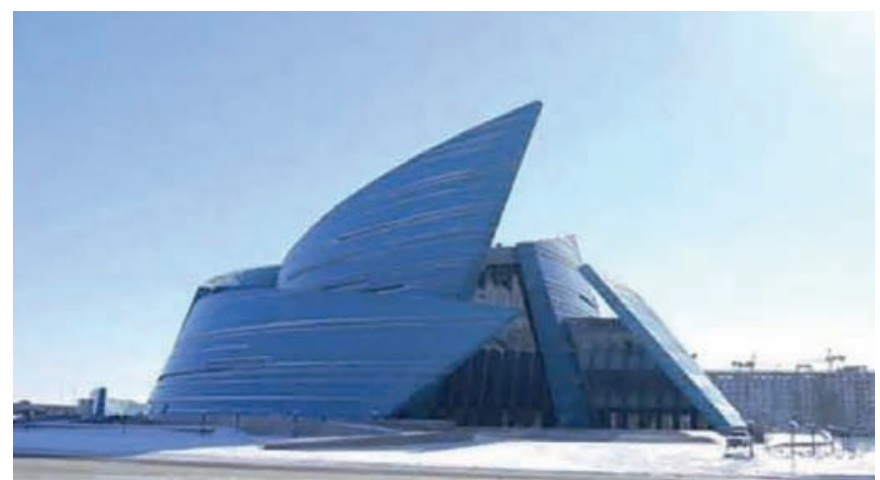

B)

Рис. 7. Примеры архитектуры Казахстана рубежа веков: а) Дворец Мира и Согласия. Нур-Султан. Идея Н. Назарбаева. Архитектор Н. Фостер); б) Дворец Ассамблеи народов Казахстана. Тараз. Архитекторы И. Байтенов, Г. Исабаев; в) концертный зал «Казахстан». Нур-Султан. Архитекторы М. Николетти, Л. Николетти; г) Президентская библиотека. Нур-Султан. Архитектор Н. Фостер

б)

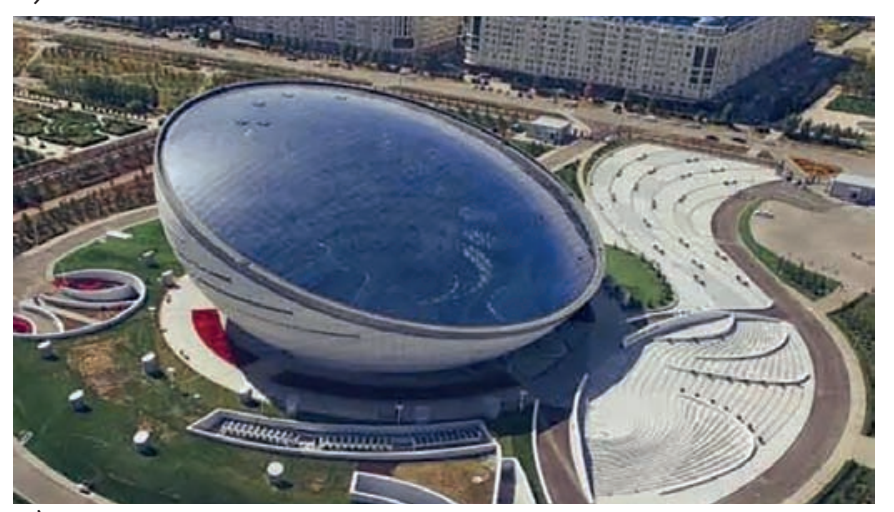

2)

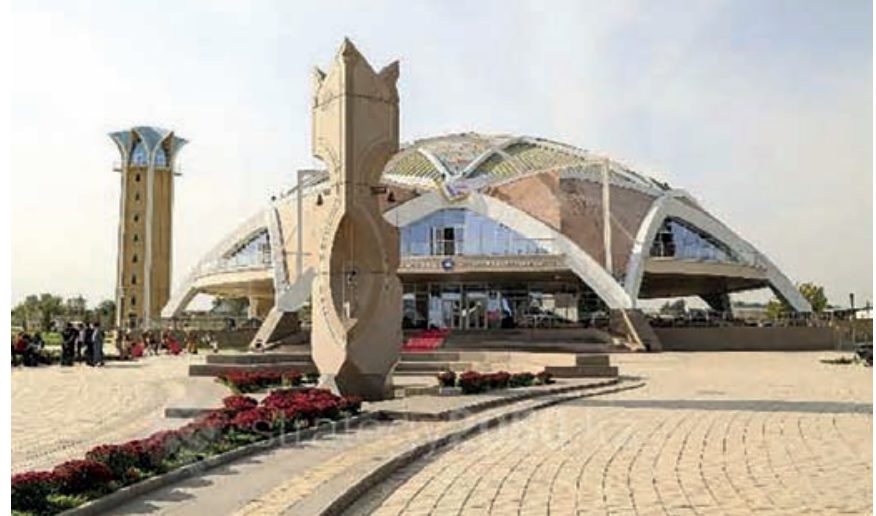

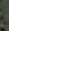


и субрегиональным особенностям Казахстана. Всё более зримой чертой казахстанской архитектуры становится её активная включённость в мировой архитектурный процесс.

Обретение государственной независимости Казахстаном активизировало и процессы архитектурной самоидентификации, имевшие многовекторную направленность. С одной стороны, это связывалось со стремлением возрождения региональных архитектурно-художественных традиций, а с другой - ускоренного адаптирования достижений зодчества наиболее экономически развитых стран. Особую окрашенность процессу придавало обилие объектов незавершённого в различной стадии строительства, которые включали как массовую застройку, так и уникальные комплексы. Часть этой совокупности составляли здания, предназначенные для организаций, либо утративших потребность в новостройках, либо исчезнувших или перепрофилированных. Соответственно, не полностью реализованные объёмно-планировочные решения в большей степени и композиционно-пластические в меньшей потеряли необходимую для немедленной реализации актуальность. Вместе с тем возник ряд новых и реорганизованных предприятий и учреждений, архитектурная интерпретация деятельности которых требовала либо кардинальной реконструкции существующих или незавершённых построек, либо нового строительства. Однако в начале периода экономическая ситуация не позволяла закладывать новостройки, и активная деятельность сосредоточилась в сфере реконструкции.

Естественное запаздывание архитектурно-художественного осмысления по-новому воспринимаемых традиций и потребность ускоренного реального строительства и реконструкции привели к широкому распространению «быстромонтируемых» тонкоэлементных облицовок, стеклопакетных витражей со стёклами различного цвета и прозрачности, а также лёгких панелей. Специфика применяемых материалов и конструкций определила своеобразную крупнодетальную пластику, а обусловленное целесообразностью сокращения сроков монтажа облицовок одноплоскостное или одноповерхностное (без акцентированного заглубления, наличников, подоконника) положение стеновых и оконных панелей привело к распространению сплошных «всефасадных остеклений» и ступенчато-уступчатых прозрачно-глухих рисунков на фасадах.

Оригинальную трансформацию облика зданий продемонстрировало проведение широких реконструкционных мероприятий во второй половине 1990-х годов. Это знаменовало появление и дальнейшее широкое распространение построек со своеобразным условно одноплоскостным или гладкоповерхностным решением фасадов, когда ведущую роль начинает играть различие применяемых облицовочных материалов, а не разноуглублённость элементов.

Однако к рубежу XX-XXI веков активная многотематическая пластика становится доминирующим направлением развития архитектурно-художественных форм. Начавшийся период стал для архитектуры Республики временем достаточно резкого увеличения темпов нового строительства. Стабильное экономиче- ское развитие привело к росту благосостояния широких слоёв населения, что в сочетании с активно совершенствующейся системой кредитования стимулировало всплеск спроса на жильё различного качества, причём, в отличие от предыдущего периода, в основном на первичном рынке. Это обусловило интенсификацию жилищного строительства. В городской застройке резко возросла этажность. Увеличились и темпы строительства общественных зданий, особенно крупных торговых и развлекательных центров, банков и страховых компаний. Не уменьшается объём реконструкций первых этажей, которые постепенно распространились и на отдалённые, «спальные» районы городов. Активно идёт мемориальное и культовое строительство.

Естественно, что эти процессы развития архитектуры Казахстана привлекают внимание исследователей [1; 3-8], в чьих трудах осмысляется как сам архитектурный процесс, так и отдельные его составляющие.

\section{Лuтература}

1. Абилов, А.Ж. Градостроительство и устойчивое развитие поселений в Казахстане / А.Ж. Абилов. - Алматы : КазГАСА, 2002. -150 с.

2. Боков, А.В. Геометрические основания архитектуры и картина мира / А.В. Боков. - М. : Издание автора, 1995. - 176 c.

3. Воличенко, О.В. Мейнстримы новейшей архитектуры - двадцать первый век / 0.В. Воличенко, Д.Д. Омуралиев. Saarbrücken : Palmarium Academic Publishing, 2013. - 449 с.

4. Дуйсебай, Е.К. Современные принципы архитектурного проектирования общественных зданий и сооружений (адаптируемые к динамике социальных перемен) / Е.К. Дуйсебай. - Алматы : КазГАСА, 2002. - 121 с.

5. Кузенбаев, Д.Ш. Архитектурные концепции проектных фирм (стилевой аспект) / Д.Ш. Кузенбаев, Г.К. Садвокасова, К.И. Самойлов. - Алматы : Строительство и Архитектура, 2019. - 186 с.

6. Куспангалиев, Б.У. Архитектура городского жилища Казахстана / Б.У. Куспангалиев. - Алматы : КазГАСА, 2000. $-184 \mathrm{c}$.

7. Приемец, О.Н. Развитие орнамента в архитектуре Алматы / О.Н. Приемец, К.И. Самойлов. - Алматы : Строительство и Архитектура, 2019. - 208 с.

8. Самойлов, К.И. Архитектура Казахстана XX века (развитие архитектурно-художественных форм) / К.И. Самойлов. - Москва-Алматы: Мари-дизайн, 2004. - 920 с.

9. Хайт, В.Л. Об архитектуре, её истории и проблемах. / В.Л. Хайт; предисл. А.П.Кудрявцева. - М. : Едиториал УРСС, 2003. -456 c.

\section{References}

1. Abilov A.Zh. Gradostroitel'stvo i ustoichivoe razvitie poselenii $\vee$ Kazakhstane [Urban planning and sustainable development of settlements in Kazakhstan- Almaty, KazGASA, 2002, 150 p. 
2. Bokov A.V. Geometricheskie osnovaniya arkhitektury $i$ kartina mira [Geometric foundations of architecture and the view of the world]. Moscow, Author's edition, 1995, 176 p.

3. Volichenko 0.V., Omuraliev D.D. Meinstrimy noveishei arkhitektury - dvadtsat' pervyi vek [Mainstreams of thelatest architecture - the twenty-first century]. - Saarbrücken, Palmarium Academic Publishing, 2013, 449 p.

4. Duisebai E.K. Sovremennye printsipy arkhitekturnogo proektirovaniya obshchestvennykh zdanii i sooruzhenii (adaptiruemye $\mathrm{k}$ dinamike sotsial'nykh peremen) [Modern principles of architectural design of public buildings and structures (adaptable to the dynamics of social change)]. Almaty, KazGASA, 2002, 121 p.

5. Kuzenbaev D.Sh., Sadvokasov, G.K., Samoilov K.I. Arkhitekturnye kontseptsii proektnykh firm (stilevoi aspekt) [Architectural concepts of design firms (a style aspect)]. Almaty, Publishing house "Building and Architecture", 2019, 186 p.
6. Kuspangaliev B.U. Arkhitektura gorodskogo zhilishcha Kazakhstana [The architecture of the city dwelling in Kazakhstan]. Almaty, KazGASA, 2000, 184 p.

7. Priemets 0.N., Samoilov K.I. Razvitie ornamenta $v$ arkhitekture Almaty [The development of ornament in the architecture of Almaty]. Almaty, Publishing house "Building and Architecture", 2019, 208 p.

8. Samoilov K.I. Arkhitektura Kazakhstana XX veka (razvitie arkhitekturno-khudozhestvennykh form) [The architecture of Kazakhstan of the XX century (the development of architectural and artistic forms)]. Moscow-Almaty, Maridizain Publ., 2004, 920 p.

9. Khait V.L. Ob arkhitekture, ee istorii i problemakh [About architecture, its history and problems], preface A.P. Kudryavtsev. Moscow, Editorial URSS, 2003, 456 p.

Куспангалиев Болат Урайханович (Алматы, Республика Казахстан). Доктор архитектуры, профессор, академик. Директор Института архитектуры и строительства им. Т. Басенова Казахского национального исследовательского технического университета им. К.И.Сатпаева (ул. Сатпаева, 22a, 050013, Алматы, Республика Казахстан. КазНИтУ им. К.И. Сатпаева); президент Казахстанского Академического центра Международной академии архитектуры (КазМААМ).

Самойлов Константин Иванович (Алматы, Республика Казахстан). Доктор архитектуры, академик Академии художеств Республики Казахстан. Профессор кафедры «Архитектура» Института архитектуры и строительства им. Т. Басенова Казахского национального исследовательского технического университета им. К.И.Сатпаева (ул. Сатпаева, 22а, 050013, Алматы, Республика Казахстан. КазНИтУ им. К.И. Сатпаева). Эл.почта: k.samoilov@satbayev.university.

Kuspangaliev Bolat U. (Almaty, Republic of Kazakhstan). Doctor of Architecture, Professor. Director of the T. Basenov Institute of Architecture and Construction of Satbayev Kazakh National Research Technical University (22a Satbayev street, Almaty, Kazakhstan, 050013. KazNRTU named after K.I. Satpayev).

Samoilov Konstantin I. (Almaty, Republic of Kazakhstan). Doctor of Architecture, Academician of the Academy of Arts of the Republic of Kazakhstan. Professor of the Department of Architecture at the the T. Basenov Institute of Architecture and Construction of Satbayev Kazakh National Research Technical University (22a Satbayev street, Almaty, Kazakhstan, 050013. KazNRTU named after K.I. Satpayev). E-mail: k.samoilov@satbayev.university. 